\title{
A fluorescence-based viability assay for Phytophthora agathidicida oospores
}

\author{
Michael J. Fairhurst ${ }^{1}$, Julie R. Deslippe ${ }^{1}$ and Monica L. Gerth ${ }^{1, *}$
}

${ }^{1}$ Centre for Biodiscovery, School of Biological Sciences, Victoria University of Wellington, Wellington 6012, Aotearoa New Zealand.

*Corresponding Author: monica.gerth@vuw.ac.nz

\begin{abstract}
Viability staining is an essential tool in many fields of microbiology. In this study, we aimed to establish a dual fluorescence method for detecting the viability of Phytophthora oospores. Phytophthora is a genus of plant pathogens in the class Oomycete that cause disease in a wide range of agriculturally and ecologically important plants. During the Phytophthora disease cycle, thick-walled oospores can be produced via sexual reproduction. These oospores are essential for long-range dispersal and long-term survival of the pathogen, and therefore methods for the study of oospores are of great interest. In this study, we tested five fluorescent dyes for their ability to stain Phytophthora agathidicida oospores: SYTO 9, FUN-1, fluorescein diacetate, propidium iodide, and TOTO-3 iodide. These dyes represented a selection of total, viable and non-viable cell stains Each dye was assessed individually, and then the best dyes were combined for dual viability staining. In this study, we have identified three dyes - SYTO 9, fluorescein diacetate and TOTO-3 - that can be used to report total, viable and non-viable oospores respectively. We further demonstrate that fluorescein diacetate and TOTO-3 can be used together for dual viability staining. This new method is quantitative and compatible with automated image analysis, allowing oospores to be rapidly and accurately assessed for viability.
\end{abstract}




\section{Introduction}

Viability staining is an essential technique in microbiology: it is widely used to evaluate susceptibility to anti-microbial drugs, monitor disinfection protocols, and/or to provide fundamental insights into microbial physiology. Methods for live/dead staining of bacteria, fungi, and mammalian cells are well-established. However, robust viability staining methods are lacking for many other microorganisms.

Phytophthora are eukaryotic microorganisms that superficially resemble filamentous fungi, but are actually members of the class Oomycete and therefore more closely related to diatoms and brown algae (Tyler et al. 2006). There are over 100 known species of Phytophthora, and many are notorious for their devastating impacts on crops and natural ecosystems (Kovacs et al. 2011, Kamoun et al. 2015, Drake et al. 2017, Corcobado et al. 2020, Susan et al. 2020). During the Phytophthora disease cycle, thick-walled oospores can be produced via sexual reproduction. These oospores are essential for long-range dispersal and long-term survival of the pathogen, and therefore methods for the study of oospores are of great interest.

Existing methods for determining the viability of Phytophthora oospores have primarily used tetrazolium bromide (MTT) or trypan blue staining (Cohen 1984, Beakes et al. 1986, Etxeberria et al. 2011). A key limitation of both these methods is that the dyes are colorimetric, and therefore the assessment of viability is subjective. For example, when stained with MTT, viable spores may appear blue, rose/purple, or reddish-brown - while nonviable oospores may appear either black or unstained. In practice, subjectivity in reading the color can affect the results. Multiple studies have found MTT staining of oospores to be subjective, unstable, and have a high rate of false positives (Etxeberria, Mendarte et al. 2011, Williams 2015). Similar issues have been observed with trypan blue staining. Besides being subjective, trypan blue assays are also time-sensitive, and the limited counting time window 
before all cells stain blue (regardless of viability) can result in false negatives (Kwok et al. 2004, Kunjeti et al. 2016, Chan et al. 2020).

The goal of this study was to develop an effective viability staining protocol for Phytophthora oospores that is quantitative - not subjective - and also amenable to automated data analysis. We chose Phytophthora agathidicida as the model system for method development. P. agathidicida a pathogen of forest trees and a clade 5 Phytophthora species. It is the causative agent of kauri dieback disease, which currently threatens the endemic kauri forests of New Zealand (Gadgil 1974, Beever et al. 2009, Waipara et al. 2013). Kauri trees are both ecologically and culturally significant (Bradshaw et al. 2020). Ecologically, kauri is a foundation species that support a large number of epiphytes and other organisms (Ahmed et al. 1987, Wyse et al. 2014). Culturally, kauri are regarded by indigenous Māori as living ancestors and therefore the trees are highly valued and considered "taonga", i.e. treasured. (Lambert et al. 2018).

Similar to many other species of Phytophthora, oospores play an important role in the persistence and spread of $P$. agathidicida. P. agathidicida is homothallic, meaning it produces oospores readily via self-fertilisation (Weir et al. 2015). Once matured, these durable 'survival spores' can persist long-term in soil and infected plant material. Movement of oospores via soil on animals, vehicles, and/or footwear is an important factor in the longdistance spread of disease (Waipara, Hill et al. 2013, Li et al. 2014, Weir, Paderes et al. 2015). Once introduced to a new area, oospores are resistant to temperature fluctuations and most chemical treatments. No practical method exists for deactivating oospores in the field; even commonly used disinfectants such as Trigene are ineffective (Bradshaw, Bellgard et al. 2020).

A fluorescence-based oospore viability assay is needed to rapidly evaluate potential oospore biocidal treatments and/or disinfection procedures. Furthermore, understanding 
oospore viability can provide insights into the optimal conditions for oospore production, survival, and germination - ultimately informing the development of improved strategies for disease management.

In this study, we tested five fluorescent dyes for their ability to stain oospores: SYTO 9, FUN-1, fluorescein diacetate, propidium iodide, and TOTO-3 iodide. These dyes represented a selection of total, viable and non-viable cell stains. Each dye was assessed individually, and then the best dyes were combined for dual viability staining. This new method is compatible with automated image analysis, allowing oospores to be rapidly and accurately assessed for viability.

\section{Materials and Methods}

\section{Materials}

P. agathidicida isolates NZFS 3770 and NZFS 3772 were provided by Scion (Rotorua, New Zealand). TOTO-3 iodide, SYTO 9, propidium iodide and FUN-1 were from Invitrogen. Fluorescein diacetate was from Sigma-Aldrich. Fluorescent dyes were provided or prepared as dimethylsulfoxide (DMSO) stock solutions and stored in small aliquots protected from light at $-20^{\circ} \mathrm{C}$. Stock solutions were diluted with sterile water to the final concentration immediately before use; the working concentrations varied according to the dye used, however, the final percentage of DMSO was $<2 \%$ in all assays.

\section{Oospore viability staining and imaging}

P. agathidicida oospores were prepared as described elsewhere (Lacey et al. 2021). Oospore numbers were estimated using disposable haemocytometers. As a negative control, nonviable oospores were produced by heat-treatment at $98{ }^{\circ} \mathrm{C}$ for $1 \mathrm{~h}$ or up to $24 \mathrm{~h}$, as indicated. Each dye was first tested individually on viable and non-viable (heat-inactivated) $P$. agathidicida NZFS 3770 oospores. The non-viable oospores were produced via heat- 
inactivation at $98^{\circ} \mathrm{C}$ for $1 \mathrm{~h}$. The fluorescent dyes were trialled using $\sim 2500$ oospores per sample. The oospores were pelleted (1200g for $10 \mathrm{~min})$ and the supernatant was removed. Oospores were resuspended in $10 \mu \mathrm{L}$ of each dye at its recommended concentration: SYTO 9 $(2 \mu \mathrm{M})$; FUN-1 $(40 \mu \mathrm{M})$; fluorescein diacetate $(200 \mu \mathrm{M})$; propidium iodide $(10 \mu \mathrm{M})$; and TOTO-3 iodide $(10 \mu \mathrm{M})$. The samples were incubated in the dark at $37^{\circ} \mathrm{C}$ for either $4 \mathrm{~h}$ (SYTO 9, propidium iodide, TOTO-3) or $24 \mathrm{~h}$ (FUN-1 and fluorescein diacetate) then imaged.

Dual staining of oospores was conducted using fluorescein diacetate and TOTO-3 iodide. Oospores from two different $P$. agathidicida isolates were tested: NZFS 3770 and NZFS 3772. Non-viable oospores were prepared by heat-treatment at $98{ }^{\circ} \mathrm{C}$ for $0-24 \mathrm{~h}$. For dual staining, oospores were first stained with $200 \mu \mathrm{M}$ fluorescein diacetate and incubated for $20 \mathrm{~h}$ incubation at $37^{\circ} \mathrm{C}$. Then, TOTO-3 iodide was added to $20 \mu \mathrm{M}$ and the samples were incubated for a further $4 \mathrm{~h}$ at $37^{\circ} \mathrm{C}$ before imaging.

Stained oospores were imaged using an Olympus BX63 fluorescence microscope with a $4 \times$ or $10 \times$ objective (with a $0.63 \times$ reductive camera lens). Green fluorescence was measured using Chroma filter 31001 (480 nm excitation center, $30 \mathrm{~nm}$ bandwidth; $535 \mathrm{~nm}$ emission center, $40 \mathrm{~nm}$ bandwidth) and an exposure of $30 \mathrm{~ms}$. Red fluorescence was measured using Chroma filter 49008 (560 nm excitation center, $40 \mathrm{~nm}$ bandwidth; $630 \mathrm{~nm}$ emission center, $75 \mathrm{~nm}$ bandwidth) with a $50 \mathrm{~ms}$ exposure.

Oospore counts were automatically generated by analysing the images with CellProfiler v3.1.8 (McQuin et al. 2018) and the data was further processed and visualised using R v3.6.0, with Rstudio v1.2.5001 (R Core Team 2017) and the ggplot2 package (Wickham 2009).

\section{Results}




\section{Viability staining with individual dyes}

Each dye was first tested individually for its specificity (e.g. specific staining of viable or non-viable cells) and potential compatibility with complementary dyes (e.g. no cross-fluorescence).

Two universal (e.g. total population) dyes were tested: SYTO9 and FUN-1 (Fig. 1). Universal dyes stain both viable and non-viable cells are therefore are a useful tool for determining total cell counts. SYTO9 is a green-fluorescent nuclei acid dye that has been used successfully to stain bacteria and fungi. SYTO 9 effectively stained both viable and nonviable oospores resulting in green fluorescence, though the fluorescence intensity was brighter for the non-viable oospores. (Fig. 1A, 1C). Stronger signal strength for non-viable cells has also been observed with SYTO9 staining of some bacteria; this is suggested to reflect differences in membrane permeability. No red cross-fluorescence was observed for SYTO9 stained oospores (Fig. 1B, 1D). The other universal dye tested - FUN1 - was originally developed as a vital stain for yeast (Millard et al. 1997). More recently, it has been used to distinguish between live and dead sporangia of Phytophthora capsici. (Lewis Ivey et al. 2014). FUN-1 is a multi-colour fluorescent probe that reports both viability and metabolic activity. The dye passively diffuses into a variety of cell types and produces green fluorescence. Subsequent processing by metabolically active cells should result in red fluorescence, while dead cells fluoresce yellow-green. When tested with oospores, FUN-1 stained oospores fluoresced both green and red, regardless of viability (Fig. 1E-1H).

For staining of viable oospores, fluorescein diacetate was tested (Fig. 2). Fluorescein diacetate is a non-fluorescent esterase substrate that permeates most cell membranes. In viable cells, it is hydrolysed by intracellular esterases to produce the green fluorescent compound fluorescein. As shown in Fig. 2A, viable oospores stained with fluorescein diacetate fluoresce green, as expected. Very little green fluorescence was observed in the 
heat-treated (i.e. non-viable) oospores (Fig. 2C), and no red cross fluorescence was observed for either sample (Fig. 3B, 3D).

The two non-viable cell stains tested were propidium iodide and TOTO-3 iodide (Fig. 3). Both of these result in red fluorescence, and therefore should be complementary to the green fluorescent dyes. Propidium iodide binds non-specifically to DNA and RNA but is highly charged and should only permeate damaged cells. Unexpectedly, both viable and nonviable oospores exhibited red fluorescence (Fig. 3B, 3D). The cause of this is unknown, though a similar phenomenon has been reported for plant cells, where it has been observed that propidium iodide binds pectin in the cell wall. TOTO-3 is also a cell-impermeant nucleic acid stain; it fared better than propidium iodide in our trials. Non-viable oospores stained with TOTO-3 iodide produced a clear red fluorescence signal (Fig. $3 \mathrm{H}$ ) with little to no green cross-fluorescence (Fig. 3E, 3G). Occasionally, a small number of oospores within the viable samples also exhibited red fluorescence (Fig. 3F). We believe this reflects heterogeneity within the population - with a small number of oospores not surviving the purification process. This is explored further in dual staining experiments described below.

Overall, three dyes were identified that successfully stained oospores when used individually: SYTO 9 (a green fluorescent universal cell stain); fluorescein diacetate (a green fluorescent viable cell stain) and TOTO-3 (a red fluorescent non-viable cell stain).

\section{Oospore dual viability staining}

Next, we tested the efficacy of the fluorescein diacetate and TOTO-3 when used together for dual viable/non-viable staining (Fig. 4). SYTO 9 could also potentially be used with TOTO-3 iodide to report total and non-viable oospore populations. However, both SYTO 9 and TOTO-3 are nucleic acid stains, and therefore binding competition between the two dyes 
could skew the results - similar to what has been observed when SYTO 9 is used in conjunction with propidium iodide (another nucleic acid stain) (Deng et al. 2020). Therefore, we chose to focus on fluorescein diacetate paired with TOTO-3. With dual stained (NZFS 3770) oospores, the majority of the viable (untreated) oospores fluoresced green (Fig. 4A). Similar to the results observed with TOTO-3, a small number of oospores within the viable (untreated) oospore population also exhibited red fluorescence (Fig. 4A). In the dual-stained non-viable oospore samples (heat-treated for $1 \mathrm{~h}$ ) most cells produced a clear red fluorescence signal, though several oospores appeared yellow (Fig. 4B). We hypothesised that the yellow oospores represent a third state: damaged, but still metabolically active. These intermediate states are commonly observed in live/dead staining of bacteria (Berney et al. 2007). To further explore this observation, we conducted a time-course of oospore heatinactivation. Oospores were incubated at $98^{\circ} \mathrm{C}$ for up to $24 \mathrm{~h}$, then dual-stained and imaged. The proportion of green (viable) and yellow (damaged) cells decrease steadily over the course of heat-treatment (Fig. S1). After 24 h of heat-treatment, only non-viable (red) oospores are observed (Fig. 4C). Similar results were obtained with a second isolate (NZFS 3772); however, the oospores of this isolate appear more robust, with higher percentages of viable and damaged oospores observed during heat-treatment (Fig. S1).

\section{Automated pipeline for quantification of oospore viability}

Finally, we sought to establish an automated image analysis pipeline that would improve the throughput of oospore viability assays. The image analysis pipeline involves two steps: (i) CellProfiler is used to generate raw counts of viable (green), non-viable (red), and damaged (yellow) oospores (ii) an R-script is used to automatically transform the data, convert the total counts to percentages, and plot the data as a bar graph. To validate this pipeline, we dual-stained different ratios of viable and non-viable oospores and analysed the 
images. Overall, the experimentally determined proportions of viable/non-viable oospores matched well to the known ratio mixtures (Fig. 5). The viability data could be fit using linear regression analysis, with coefficients of determination $\left(R^{2}\right)$ of $\geq 0.9$ for both dyes.

\section{Discussion}

We have identified three dyes - SYTO 9, fluorescein diacetate and TOTO-3 - that can be used to report total, viable and non-viable oospores respectively. We further demonstrate that fluorescein diacetate and TOTO-3 can be used together for dual viability staining. Two key advantages of this new fluorescence-based method are that it quantitatively distinguishes between viable and non-viable oospores and the resulting data can be coupled with automated image analysis. This increases both the throughput and reliability of viability assays - particularly in comparison to colorimetric dyes such as MTT where the color change is assessed subjectively. These dyes are also (in theory) compatible with flow cytometry. Future studies could explore the use of this dual viability staining method with flow cytometry to further improve the reliability and throughput, allowing much larger populations to be assessed and/or sorted.

While we initially developed this assay to assess the susceptibility of oospores to potential biocides/treatments there are many other applications. For example, viability screening can be used to assess oospore viability post-purification (to ensure batch-to-batch reproducibility) or to monitor changes in oospore viability over time. Our results also highlighted potential differences amongst isolates in the resistance of oospores to heattreatment. Previous studies have established that there is variability in virulence among $P$. agathidicida isolates (Drake and Jones 2017). However, potential differences in oospore robustness or resistance to treatments have not yet been explored; this will be an interesting avenue for future studies. 
bioRxiv preprint doi: https://doi.org/10.1101/2021.10.17.464154; this version posted October 18,2021 . The copyright holder for this preprint (which was not certified by peer review) is the author/funder, who has granted bioRxiv a license to display the preprint in perpetuity. It is made available under aCC-BY-NC-ND 4.0 International license.

Phytophthora species remain some of the world's most destructive plant pathogens.

This improved method for viability staining of oospores will hopefully facilitate further studies on this key part of the Phytophthora disease cycle.

\section{Funding}

This work was supported via strategic research funds from the School of Biological Sciences at Victoria University of Wellington. MJF is supported by a Marsden Grant (SUB1877) Doctoral Scholarship.

\section{References}

Ahmed, M. and Ogden, J. (1987). Population dynamics of the emergent conifer Agathis australis (D. Don) Lindl. (Kauri) in New Zealand I. Population structures and tree growth rates in mature stands. N.Z. J. Bot. 25: 217-229.

Beakes, G. W., El-Hamalawi, Z. A. and Erwin, D. C. (1986). Ultrastructure of mature oospores of Phytophthora megasperma f.sp. medicaginis: preparation protocols and effects of MTT vital staining and permanganate pre-treatment. Trans. Br. Mycol. Soc. 86: $195-206$.

Beever, R. E., Waipara, N. W., Ramsfield, T. D., Dick, M. A. and Horner, I. J. (2009). Kauri (Agathis australis) under threat from Phytophthora? Proceedings of the 4th Meeting of the IUFRO Working Party, Monterey, California.

Berney, M., Hammes, F., Bosshard, F., Weilenmann, H.-U. and Egli, T. (2007). Assessment and interpretation of bacterial viability by using the LIVE/DEAD BacLight kit in combination with flow cytometry. Appl. Environ. Microbiol. 73: 3283-3290. 
bioRxiv preprint doi: https://doi.org/10.1101/2021.10.17.464154; this version posted October 18,2021 . The copyright holder for this preprint (which was not certified by peer review) is the author/funder, who has granted bioRxiv a license to display the preprint in perpetuity. It is made available under aCC-BY-NC-ND 4.0 International license.

Bradshaw, R. E., Bellgard, S. E., Black, A., Burns, B. R., Gerth, M. L., McDougal, R. L., .. . Horner, I. J. (2020). Phytophthora agathidicida: research progress, cultural perspectives and knowledge gaps in the control and management of kauri dieback in New Zealand. Plant Pathol. 69: 3-16.

Chan, L. L.-Y., Rice, W. L. and Qiu, J. (2020). Observation and quantification of the morphological effect of trypan blue rupturing dead or dying cells. PLoS One 15: $\mathrm{e} 0227950$.

Cohen, S. D. (1984). Detection of mycelium and oospores of Phytophthora Megasperma forma specialis Glycinea by vital stains in soil. Mycologia 76: 34-39.

Corcobado, T., Cech, T. L., Brandstetter, M., Daxer, A., Hüttler, C., Kudláček, T., . . Jung, T. (2020). Decline of European Beech in Austria: Involvement of Phytophthora spp. and contributing biotic and abiotic factors. Forests 11: 895.

Deng, Y., Wang, L., Chen, Y. and Long, Y. (2020). Optimization of staining with SYTO 9/propidium iodide: interplay, kinetics and impact on Brevibacillus brevis. BioTechniques.

Drake, B. and Jones, G. (2017). Public value at risk from Phytophthora ramorum and Phytophthora kernoviae spread in England and Wales. J. Environ. Manage. 191: 136144.

Etxeberria, A., Mendarte, S. and Larregla, S. (2011). Determination of viability of Phytophthora capsici oospores with the tetrazolium bromide staining test versus a plasmolysis method. Rev. Iberoam. Micol. 28: 43-49.

Gadgil, P. D. (1974). Phytophthora heveae, a pathogen of kauri. N.Z. J. For. Sci. 4. Kamoun, S., Furzer, O., Jones, J. D. G., Judelson, H. S., Ali, G. S., Dalio, R. J. D., . . Govers, F. (2015). The Top 10 oomycete pathogens in molecular plant pathology. Mol. Plant Pathol. 16: 413-434. 
bioRxiv preprint doi: https://doi.org/10.1101/2021.10.17.464154; this version posted October 18,2021 . The copyright holder for this preprint (which was not certified by peer review) is the author/funder, who has granted bioRxiv a license to display the preprint in perpetuity. It is made available under aCC-BY-NC-ND 4.0 International license.

Kovacs, K., Václavík, T., Haight, R. G., Pang, A., Cunniffe, N. J., Gilligan, C. A. and Meentemeyer, R. K. (2011). Predicting the economic costs and property value losses attributed to sudden oak death damage in California (2010-2020). J. Environ. Manage. 92: $1292-1302$.

Kunjeti, S. G., Anchieta, A., Subbarao, K. V., Koike, S. T. and Klosterman, S. J. (2016). Plasmolysis and vital staining reveal viable oospores of Peronospora effusa in spinach seed lots. Plant Dis. 100: 59-65.

Kwok, A. K. H., Yeung, C.-K., Lai, T. Y. Y., Chan, K.-P. and Pang, C. P. (2004). Effects of trypan blue on cell viability and gene expression in human retinal pigment epithelial cells. Br. J. Ophthalmol. 88: 1590-1594.

Lacey, R. F., Fairhurst, M. J., Daley, K. J., Ngata-Aerengamate, T. A., Patterson, H. R., Patrick, W. M. and Gerth, M. L. (2021). Assessing the effectiveness of oxathiapiprolin towards Phytophthora agathidicida, the causal agent of kauri dieback disease. BioRxiv. doi: $10.1101 / 2021.03 .10 .434845$.

Lambert, S., Waipara, N., Black, A., Mark-Shadbolt, M. and Wood, W. (2018). Indigenous biosecurity: Māori responses to kauri dieback and myrtle rust in Aotearoa New Zealand. The Human Dimensions of Forest and Tree Health: Global Perspectives. J. Urquhart, M. Marzano and C. Potter. Cham, Springer International Publishing: 109-137.

Lewis Ivey, M. L. and Miller, S. A. (2014). Use of the vital stain FUN-1 indicates viability of Phytophthora capsici propagules and can be used to predict maximum zoospore production. Mycologia 106: 362-367.

Li, A., Williams, N. M., Fenwick, S. G., Hardy, G. and Adams, P. J. (2014). Potential for dissemination of Phytophthora cinnamomi by feral pigs via ingestion of infected plant material. Biol. Invasions 16: 765-774. 
bioRxiv preprint doi: https://doi.org/10.1101/2021.10.17.464154; this version posted October $18,2021$. The copyright holder for this preprint (which was not certified by peer review) is the author/funder, who has granted bioRxiv a license to display the preprint in perpetuity. It is made available under aCC-BY-NC-ND 4.0 International license.

McQuin, C., Goodman, A., Chernyshev, V., Kamentsky, L., Cimini, B. A., Karhohs, K. W., . . Carpenter, A. E. (2018). CellProfiler 3.0: next-generation image processing for biology. PLoS Biol. 16: e2005970.

Millard, P. J., Roth, B. L., Thi, H. P. T., Yue, S. T. and Haugland, R. P. (1997). Development of the FUN-1 family of fluorescent probes for vacuole labeling and viability testing of yeasts. Mycologia 63: 2897-2905.

R Core Team (2017). R: A language and environment for statistical computing. Vienna, Austria, R Foundation for Statistical Computing.

Susan, J. F., Janice, A., Diana, B., Janell, H. and Alisa, S. (2020). Phytophthora pathogens threaten rare habitats and conservation plantings. Sibbaldia.

Tyler, B. M., Tripathy, S., Zhang, X., Dehal, P., Jiang, R. H. Y., Aerts, A., . . Boore, J. L. (2006). Phytophthora genome sequences uncover evolutionary origins and mechanisms of pathogenesis. Science 313: 1261-1266.

Waipara, N. W., Hill, S., Hill, L. M. W., Hough, E. G. and Horner, I. J. (2013). Surveillance methods to determine tree health, distribution of kauri dieback disease and associated pathogens. N.Z. Plant Prot. 66: 235-241.

Weir, B. S., Paderes, E. P., Anand, N., Uchida, J. Y., Pennycook, S. R., Bellgard, S. E. and Beever, R. E. (2015). A taxonomic revision of Phytophthora clade 5 including two new species, Phytophthora agathidicida and P. cocois. Phytotaxa 205: 21-38.

Wickham, H. (2009). ggplot2: Elegant Graphics for Data Analysis., Springer-Verlag New York.

Williams, N. M. (2015). Deactivation of oospores of Phytophthora taxon Agathis -Phase 2. Kauri Dieback Programme. New Zealand: 1-24. 
Wyse, S. V., Burns, B. R. and Wright, S. D. (2014). Distinctive vegetation communities are associated with the long-lived conifer Agathis australis (New Zealand kauri, Araucariaceae) in New Zealand rainforests. Austral Ecol. 39: 388-400. 
Viable
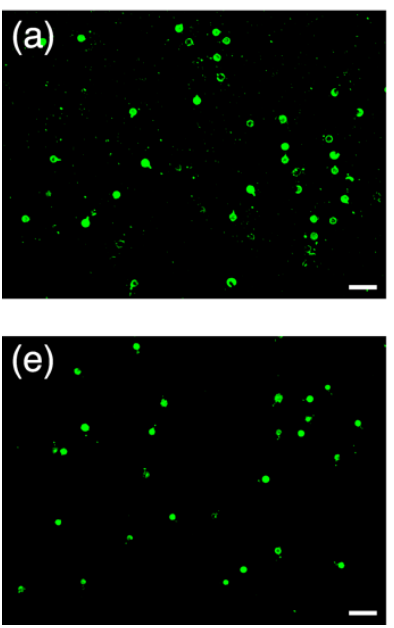
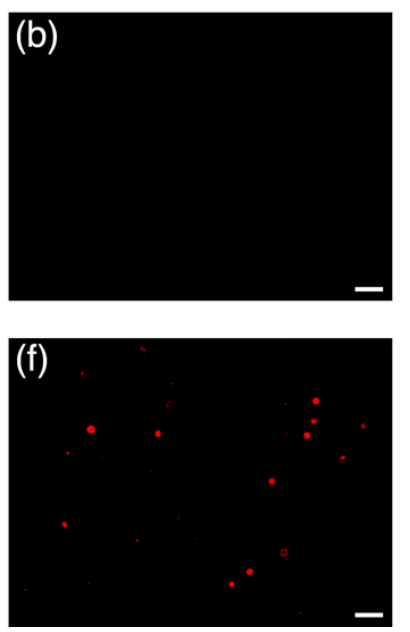

Non-viable
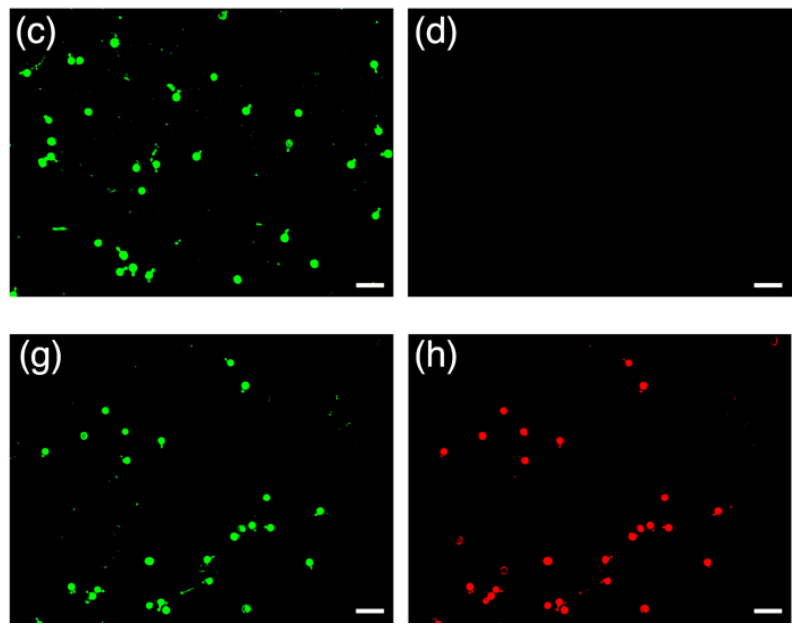

Figure 1. Universal (total cell count) dyes. $P$. agathidicida NZFS 3770 oospores were

stained with SYTO 9 (a-d) or FUN-1 (e-h). Each dye was tested with viable and non-viable (heat-treated) oospores and imaged using both green and red fluorescence filters. (a-d) SYTO 9 is a green-fluorescent nucleic acid dye that stains both (a) viable and (c) non-viable oospores, with no red cross-fluorescence (b,d). (e-h) FUN-1 stained oospores fluoresced both green $(\mathbf{e}, \mathbf{g})$ and red $(\mathbf{f}, \mathbf{h})$ regardless of viability. Each panel is representative of three independent experiments. Scale bar $=100 \mu \mathrm{m}$. 

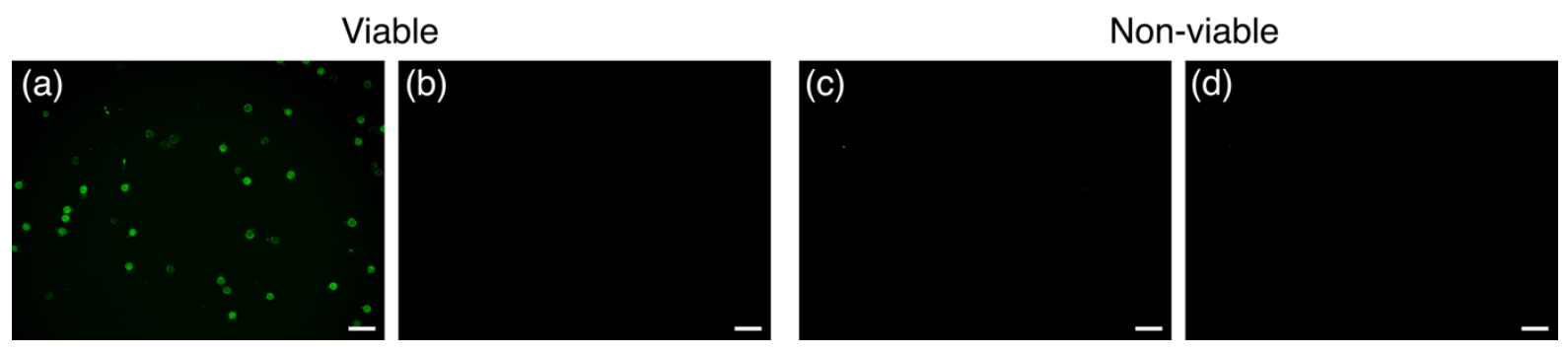

Figure 2. Viable cell dye: fluorescein diacetate. Viable and non-viable (heat-treated)

P. agathidicida NZFS 3770 oospores were stained with fluorescein diacetate and imaged using both green and red fluorescence filters. Fluorescein stains viable oospores green (a) with no signal observed for non-viable oospores (c) and no red cross-fluorescence (b,d). Each panel is representative of three independent experiments. Scale bar $=100 \mu \mathrm{m}$. 


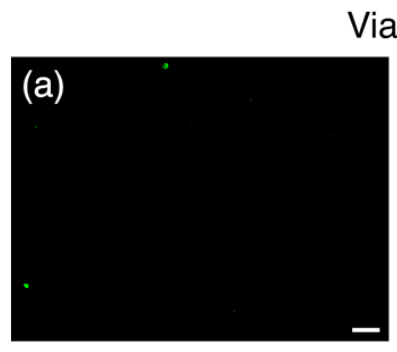

Viable
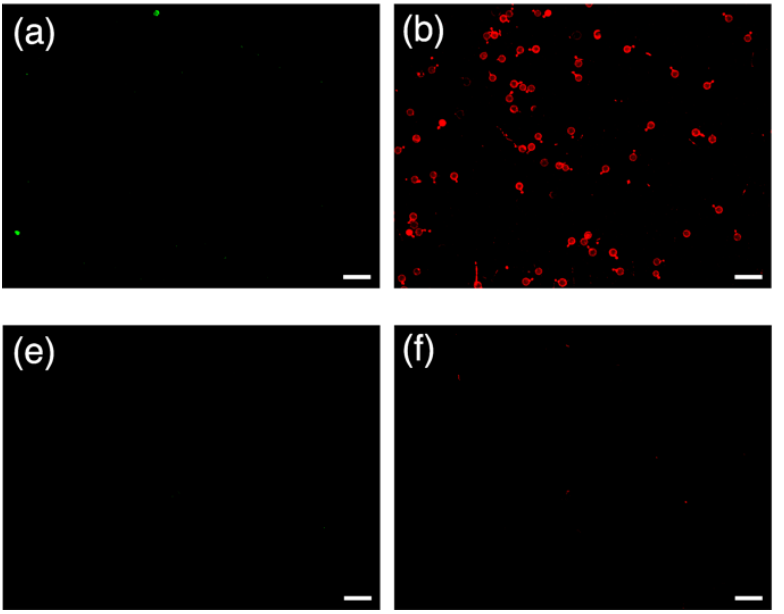

Non-viable

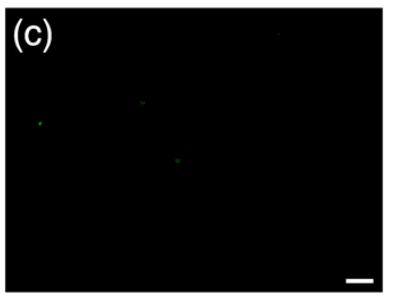

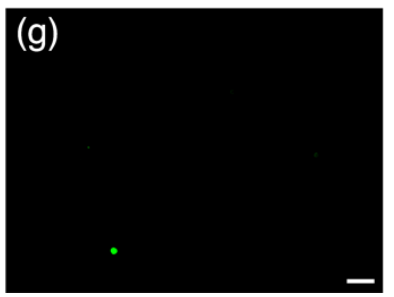

Figure 3. Non-viable dyes. $P$. agathidicida NZFS 3770 oospores were stained with propidium iodide (a-d) or TOTO-3 (e-h). Each dye was tested with viable and non-viable (heat-treated) oospores and imaged using both green and red fluorescence filters. (a-d) Propidium iodide stained oospores fluoresced red, regardless of viability $(\mathbf{b}, \mathbf{d})$; no green cross-fluorescence was observed (a,c). (e-h) TOTO-3 stained non-viable oospores red (h); there was no effect on viable oospores (f) and minimal green cross-fluorescence (e, g). Each panel is representative of three independent experiments. Scale bar $=100 \mu \mathrm{m}$. 

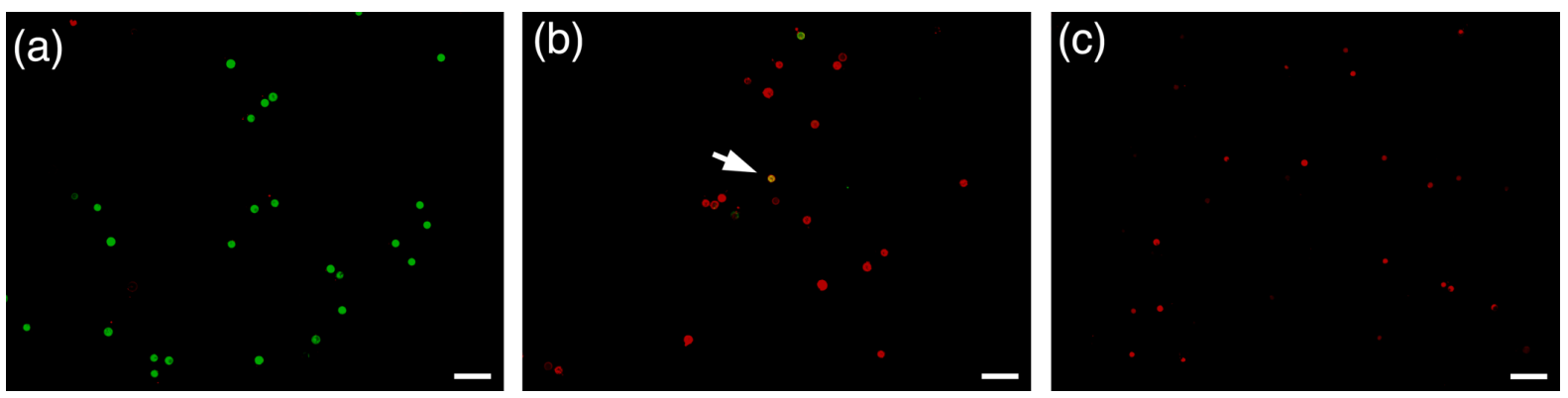

Figure 4. Dual staining of oospores and time-course of heat-inactivation. P. agathidicida

NZFS 3770 oospores were heated to $98^{\circ} \mathrm{C}$ before dual-staining with fluorescein diacetate and TOTO-3 iodide. Merged images (green/red fluorescence) are shown. (a) $0 \mathrm{~h}$ heat treatment (b) $1 \mathrm{~h}$ heat-treatment (c) $24 \mathrm{~h}$ heat-treatment. The arrow in panel (b) highlights a yellow (damaged, but still viable) oospore. Images are representative of three independent experiments. Scale bar $=100 \mu \mathrm{m}$. 


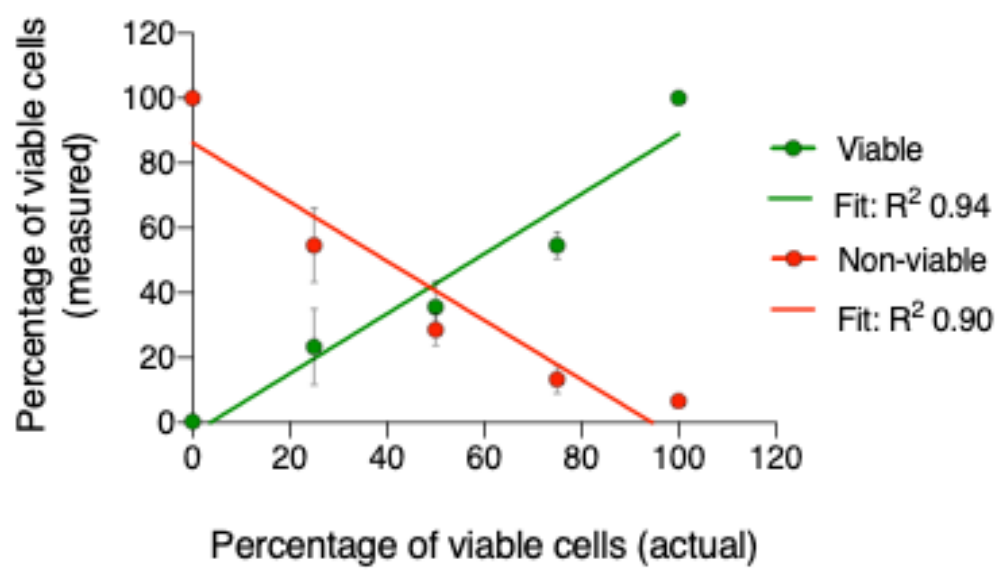

Figure 5. Quantification of oospore viability. Viable and non-viable oospores were mixed in known proportions, dual stained with fluorescein diacetate and TOTO-3, and the stained oospores automatically counted using CellProfiler. Green circles represent viable (fluorescein diacetate-stained) oospores; red circles represent non-viable (TOTO-3 iodide stained) oospores. Green and red lines represent linear regression of the viable and non-viable data, respectively. Data presented are the mean of three independent experiments; error bars represent the standard error of the mean. 